\title{
THE LETTER OF THE LAW: THE SCOPE OF THE INTERNATIONAL LEGAL OBLIGATION TO PROSECUTE HUMAN RIGHTS CRIMES
}

\author{
MICHAEL SCHARF \\ । \\ INTRODUCTION
}

In the past several years, A rgentina, Cambodia, Chile, EI Salvador, G uatemala, $\mathrm{H}$ aiti, U ruguay, and South A frica have each granted amnesty ${ }^{1}$ to members of the former regime that commanded death squads that tortured and killed thousands of civilians within their respective countries. ${ }^{2}$ With respect to four of these countries (Cambodia, EI Salvador, H aiti, and South A frica), the $\mathrm{U}$ nited N ations pushed for, helped negotiate, and/or endorsed the granting of amnesty as a means of restoring peace and democratic government. ${ }^{3}$ A the preparatory conference for the establishment of a permanent international criminal court in A ugust 1997, the U.S. D elegation circulated a paper suggesting that the proposed permanent court should take into account such amnesties in the interest of international peace and national reconciliation when deciding whether to prosecute. ${ }^{4}$

N umerous scholars have made the case against granting amnesty to those who commit violations of international humanitarian law (the laws of war), or who commit other serious human rights crimes (genocide, torture, and crimes

\footnotetext{
Copyright $\odot 1997$ by L aw and Contemporary Problems

*A ssociate Professor of $L$ aw and Director of the Center for International Law and Policy, New England School of Law; formerly A ttorney-A dviser, O ffice of the L egal A dviser, U.S. D epartment of State, 1989-1993.

1. The term "amnesty" is derived from the G reek word "amnestia," which means forgetfulness or oblivion. See Norman Weisman, A H istory and Discussion of A mnesty, 4 COLUM. HUM. RTS. L. REV . 520, 520 (1972). A mnesty is an act of sovereign power "decriminalizing" a past offense. See Progress Report on the Q uestion of the I mpunity of P erpetrators of $\mathrm{H}$ uman Rights Violations, Commission on H uman Rights, J uly 19, 1993, U.N. D oc. E/CN.4/Sub.2/1993/6, at 12. A mnesty is generally exercised on behalf of certain classes of persons who are subject to trial but have not yet been prosecuted or convicted. A pardon is to be contrasted from amnesty in that it does not overlook the offense or expunge the conviction. See W eisman, supra, at 530.

2. See Naomi Roht-A rriaza, State Responsibility to Investigate and Prosecute Grave Human Rights Violations in International Law, 78 CAL. L. REV. 451, 458-61, 484 n.187 (1990); Michael P. Scharf, Swapping A mnesty for Peace: Was There a Duty to Prosecute International Crimes in Haiti?, 31 TEXA S INT'L L.J. 1, 15-18 (1996).

3. See M ichael V ickery \& Naomi R oht-A rriaza, Human Rights in Cambodia, in IM PUNITY AND HuMAN RIGHTSIN INTERNATIONA L LA W AND PRA CTICE 251 (Naomi R oht-A rriaza ed., 1995).

4. See ICC PrepC on-A ugust 1997, U .S. D elegation D raft (R ev.), on file with author.
} 
against humanity). ${ }^{5}$ Specifically, prosecuting the perpetrators of such crimes is seen as necessary to discourage future offenses, deter vigilante justice, promote reconciliation, and reinforce respect for the law and the new democratic regime. ${ }^{6} Y$ et, according to the U .S. State D epartment, these policies must be balanced against the need to close "a door on the conflict of a past era" and "to encourage the surrender or reincorporation of armed dissident groups," which can facilitate the transition to democracy. ${ }^{7}$

Before weighing the policies for and against granting amnesty in any given case, government and international organization officials must first determine whether there exists an international law obligation to prosecute the particular offense. It is one thing to suggest that in a given case the decision not to prosecute violators represented a poor policy judgment; it is quite another to conclude that such a decision violated international law. Were such a conclusion possible, the decision to forego prosecution could be challenged before domestic courts ${ }^{8}$ or in international fora. ${ }^{9}$ In addition, given the role of the $U$ nited $\mathrm{N}$ ations in some of these cases, such a determination would seriously damage the credibility of the $U$ nited $N$ ations as an institution committed to the rule of law. ${ }^{10}$ Finally, it would be highly inappropriate for an international criminal court to defer to a national amnesty in a situation where the amnesty violates obligations contained in the very international conventions that make up the court's subject matter jurisdiction.

5. Seegenerally A SPEn InSt., StA TE CRIMES: Punishment OR PARDON-PAPERSANd REPORT OF THE CONFERENCE (1989).

6. Seeld.

7. ICC PrepCon, supra note 4 , at 1 .

8. When Salvadoran citizens brought suit before domestic courts in an attempt to have the EI Salvador amnesty law declared invalid, the Supreme Court of J ustice of EI Salvador ruled that the granting of amnesty in these circumstances constituted a political question that the courts lacked competence to address. See EI Salvador: Supreme Court of J ustice D ecision on the A mnesty Law, Proceedings No. 10-93 (May 20, 1993), reprinted in 3 TRANSNATIONAL JUSTICE: HOW EMERGING DEM OCRA CIES RECKON WITH FORMER REGIMES 549 (Neil Kritz ed., 1995). However, the issue before the Court was the constitutionality of the amnesty law in relation to the powers of legislature, not whether the amnesty law was invalid as a violation of international law. Indeed, the Court made clear that "there are cases where there is constitutional jurisdictional control over amnesty, and it is the competence of the Constitutional Chamber to pronounce itself over its [merits or lack of merits] ab initio, or to initiate proceedings, in accordance [with] the case, inasmuch they are filed before the Chamber." Id.

9. "Challenges to amnesty laws enacted in A rgentina, EI Salvador, Suriname, and U ruguay have been lodged with the Inter-A merican Commission on $\mathrm{H}$ uman R ights of the Organization of A merican States." D ianne Orentlicher, Settling A ccounts: The Duty to Prosecute H uman Rights Violations of a Prior Regime, 100 Y A LE L.J . 2537, 2540 n.5 (1991).

10. A rticle I (1) of the U.N. Charter provides:

The Purposes of the $U$ nited Nations are ... to maintain international peace and security, and to that end: to take effective collective measures for the prevention and removal of threats to the peace, and for the suppression of acts of aggression or other breaches of the peace, and to bring about by peaceful means, and in conformity with the principles of justice and international law, adjustment or settlement of international disputes or situations which might lead to a breach of the peace.

U.N. CHARTER art.1, para. 1 (emphasis added). 
II

\section{Sourcesof an Obligation to Prosecute}

\section{A . Crimes D efined in International Conventions}

The prerogative of a state to issue an amnesty for an offense can be circumscribed by treaties to which the state is a party. A s A rticle 27 of the V ienna Convention on the Law of Treaties provides, "[a] party may not invoke the provisions of its internal law as justification for failure to perform a treaty." ${ }^{11}$ There are several international conventions that clearly provide for a duty to prosecute the humanitarian or human rights crimes defined therein. Of particular note are the Geneva Conventions of 1949, the G enocide Convention, and the Torture Convention. When these Conventions are applicable, the granting of amnesty to persons responsible for committing the crimes defined therein would constitute a breach of a treaty obligation for which there can be no excuse or exception. It is noteworthy, however, that these Conventions were all negotiated in the context of the cold war and by design apply only to a narrow range of situations.

1. The $1949 \mathrm{G}$ eneva Conventions. The four $\mathrm{G}$ eneva Conventions were negotiated in 1949 to codify the international rules relating to the treatment of prisoners of war and civilians in occupied territory. The G eneva Conventions are among the most widely ratified treaties in the world. ${ }^{12} \mathrm{E}$ ach of the Conventions contains a specific enumeration of "grave breaches," which are war crimes under international law for which there is individual criminal liability and for which states have a corresponding duty to prosecute. ${ }^{13} \mathrm{G}$ rave breaches include willful killing, torture, or inhuman treatment, including biological experiments, willfully causing great suffering or serious injury to body or health, extensive destruction of property not justified by military necessity, willfully depriving a civilian of the rights of a fair and regular trial, and unlawful confinement of a civilian. ${ }^{14}$

11. V ienna Convention on the Law of Treaties, M ay 23, 1969, U.N. D oc. A/CONF.39/27 (entered into force for Haiti on Jan. 27, 1990), reproduced in BARRY E. CARTER \& PHILLIPR. TRIMBLE, INTERNATIONA L LA W: SELECTED D OCUMENTS 55 (1995).

12. A s of February 1, 1994, 185 states were party to the Geneva Conventions. See Carla E delenbos, Human Rights Violations: A Duty To Prosecute?, 7 LEIDEN J. INT'L L., A utumn 1994, at 5, 12 n.21.

13. See VIRGINIA MORRIS \& MICHAEL P. SCHARF, AN INSIDER'S GUIDE TO THE INTERnATIONAL CRIMINAL TRIBUNAL FOR THE FORMER YUGOSLAVIA 64-65 (1995).

14. See A rticle 50 of the Geneva Convention For the A melioration of the Condition of the Wounded and Sick in A rmed Forces in the Field, A ug. 12, 1949, 6 U .S.T. 311, T.I.A.S. N o. 3362, 75 U.N.T.S. 31 [hereinafter G eneva Convention I]; A rticle 51 of the $G$ eneva Convention for the A melioration of the Condition of the W ounded, Sick, and Shipwrecked M embers of the A rmed Forces at Sea, A ug. 12, 1949, 6 U.S.T. 3217, T.I.A.S. N o. 3363, 75 U.N.T.S. 85 [hereinafter Geneva Convention II ]; A rticle 130 of the $G$ eneva Convention R elative to the Treatment of Prisoners of War, A ug. 12, 1949, 6 U.S.T. 3316, T.I.A.S. N o. 3364, 75 U.N.T.S. 135 [hereinafter Geneva Convention III ]; and A rticle 147 of the Geneva Convention Relative to the Protection of Civilian Persons in Time of War, A ug. 12, 1949, 6 U .S.T. 3516, T.I .A .S. N 0. 3365, 75 U .N.T.S. 287 [hereinafter Geneva Convention IV ]. 
Parties to the G eneva Conventions have an obligation to search for, prosecute, and punish perpetrators of grave breaches of the Conventions unless they choose to hand over such persons for trial by another state party. ${ }^{15}$ The Commentary to the Conventions, which is the official history of the negotiations leading to the adoption of these treaties, ${ }^{16}$ confirms that the obligation to prosecute is "absolute," meaning, inter alia, that states parties can under no circumstances grant perpetrators immunity or amnesty from prosecution for grave breaches. ${ }^{17}$

The duty to prosecute is, however, limited to the context of international armed conflict. ${ }^{18}$ There are two reasons why the Geneva Conventions would not, therefore, apply to the above cited examples of countries that refused to prosecute persons responsible for atrocities. First, there is a high threshold of violence necessary to constitute a genuine armed conflict, as distinct from lower level disturbances such as riots or isolated and sporadic acts of fighting. ${ }^{19}$ Second, the violence in those countries did not have an international character as recognized by the $\mathrm{G}$ eneva Conventions. The international conflict requirement derives from common article 2 of the four Conventions, which describes such conflicts as cases of declared war or any other armed conflict that may arise between two or more of the contracting powers, even if the state of war is not recognized by one of them, and cases of partial or total occupation of the territory of the contracting party, even if such occupation meets no armed resistance. $^{20}$

2. The Genocide Convention. The Genocide Convention entered into force on January 12,1952 , and has been widely ratified. ${ }^{21}$ Like the G eneva Conventions, the Genocide Convention provides an absolute obligation to prosecute persons responsible for genocide as defined in the Convention. ${ }^{22}$ The

15. Geneva Convention I, supra note 14, art. 51; G eneva Convention II, supra note 14, art. 52; Geneva Convention III, supra note 14, art. 131; G eneva Convention IV, supra note 14, art. 148.

16. A ccording to A rticle 32 of the $V$ ienna Convention on the Law of Treaties, "[r]ecourse may be had to supplementary means of interpretation, including the preparatory work of the treaty and the circumstances of its conclusion, in order to ... determine the meaning" when the text of a treaty provision "leaves the meaning ambiguous or obscure." U.N. D oc. A/Conf. 39/27 (M ay 23, 1969), reprinted in 63 A M. J. INT'L L. 875 (1969).

17. See MORRIS \& SCHARF, supra note 13 , at 114 n.356 and accompanying text, 341; see also THEODOR MERON, HUMAN RIGHTS AND HUMANITARIAN NORMS AS CUSTOMARY LAW 215 (1989) ( $G$ eneva Conventions not subject to derogation).

18. See Prosecutor v. Tadic, Case IT-94-1-T, D ecision on J urisdiction 68 (O ct. 2, 1995); see also 1 MORRIS \& SCHARF, supra note 13, at 54, 64-65, 114 n.356. But see J ordan J. Paust, A pplicability of International Criminal L aws to E vents in the Former Y ugoslavia, 9 A M. J . INT'L L. \& POL'Y 499, 511-12 (1994) (arguing that serious violations of Common A rticle 3 of the $G$ eneva Conventions, which applies to internal armed conflict, can also be deemed "grave breaches" carrying the duty to prosecute).

19. See Theodor Meron, Human Rights in INTERnal Strife: Their INTERnational PROTECTION 46 (1987). For a discussion of the historical development of the notions of "war" and "armed conflict," see Werner Meng, War, in 4 ENCY CLOPEDIA OF PUBLIC INTERNATIONAL LAW 282 (1982); K arl J osef Partsch, Armed Conflict, in 1 EnCY CLOPEDIA OF PUBLIC INTERNATIONAL LAW 249 (1992).

20. See A rticle 2 of G eneva Conventions I, II, III, and IV , supra note 14 .

21. A s of D ecember 31, 1993, 112 states were parties. See E delenbos, supra note 12 , at 5, 6 .

22. A rticle 4 of the $\mathrm{G}$ enocide Convention states: "Persons committing genocide or any of the 
Convention defines genocide as one of the following acts when committed "with intent to destroy, in whole or in part, a national, ethnical, racial, or religious group, as such":

(a) Killing members of the group;

(b) Causing serious bodily or mental harm to members of the group;

(c) D eliberately inflicting on the group conditions of life calculated to bring about its physical destruction in whole or in part;

(d) I mposing measures intended to prevent births within the group;

(e) Forcibly transferring children of the group to another group. ${ }^{23}$

The $\mathrm{G}$ enocide Convention contains two limitations that rendered it inapplicable to most of the above cited cases. First, the Convention applies only to those who have the specific intent literally to destroy a substantial portion of the population of a target group. ${ }^{24}$ Second, the victims must constitute one of the groups enumerated in the G enocide Convention, namely, national, ethnic, racial, or religious. In this respect, it is noteworthy that the drafters of the Genocide Convention deliberately excluded acts directed against "political groups" from the Convention's definition of genocide. ${ }^{25}$

3. The Torture Convention. The Torture Convention entered into force on J une 26, 1987, and currently has only 79 parties. $^{26}$ The Convention defines "torture" as

any act by which severe pain or suffering, whether physical or mental, is intentionally inflicted on a person for such purposes as obtaining from him or a third person information or a confession, punishing him for an act he or a third person has committed or is suspected of having committed, or intimidating or coercing him or a third person, or for any reason based on discrimination of any kind, when such pain or suffering is

other acts enumerated in article 3 shall be punished, whether they are constitutionally responsible rulers, public officials or private individuals." Convention on the Crime of G enocide, 9 D ecember 1948, 78 U.N.T.S. 277 [hereinafter Genocide Convention]. A rticle 5 requires states to "provide effective penalties" for persons guilty of genocide. G enocide Convention art. $\mathrm{V}$.

23. Id. art. II.

24. Seeja son S. A brams \& Stever. Ratner, Striving for Justice: A CCOUNTABility and THE CRIMES OF THE KHMER ROUGE 39 (1995) (unpublished State Department Report which concludes that "most commentators assert that the number of individuals intended to be destroyed must be substantial, in light of the Convention's emphasis on acts against large numbers, rather than individuals).

25. The exclusion of "political groups" was due in large part to the fact that the Convention was negotiated during the Cold War, when the Soviet U nion and other totalitarian governments feared that they would face interference in their internal affairs if genocide were defined to include acts committed to destroy political groups. A ccording to Professor Kuper, "one may fairly say that the delegates, after all, represented governments in power, and that many of these governments wished to retain an unrestricted freedom to suppress political opposition." LEO KUPER, GENOCIDE: ITS POLITICAL U SE IN THE TWENTIETH CENTURY 30 (1982).

26. Convention A gainst Torture and $O$ ther Cruel, Inhuman, or D egrading Treatment or Punishment, opened for signature Feb. 4, 1985, 39 U.N. GA OR Supp. (No. 51) at 197, U.N. D oc. A/39/51 (1984), reprinted in 23 I.L.M. 1027 (1984), as modified, 24 I.L.M. 535 (1984) (entered into force J une 26,1987 ) [hereinafter Torture Convention]; see $E$ delenbos, supra note 12 , at 5,7 (reporting that on D ecember 31, 1993, 79 states were party to the Convention). 
inflicted by or at the instigation of or with the consent or acquiescence of a public official or other person acting in an official capacity. It does not include pain or suffering arising only from, inherent in or incidental to lawful sanctions. ${ }^{27}$

$M$ any of the brutal atrocities committed in the countries listed above would fall within this definition.

The Torture Convention requires each state party to ensure that all acts of torture are offenses under its internal law, ${ }^{28}$ establish its jurisdiction over such offenses in cases where, inter alia, the alleged offender is a national of the state, ${ }^{29}$ and if such a state does not extradite the alleged offender, the Convention requires it to submit the case to its competent authorities for the purpose of prosecution. ${ }^{30}$ Several commentators have argued that the peculiar wording of the Torture Convention might allow for some types of amnesties, whereas the $\mathrm{G}$ enocide Convention contains a more air-tight obligation to prosecute and punish. ${ }^{31}$ The argument focuses on the fact the $G$ enocide Convention requires that persons who commit genocide "shall be punished" and requires states to "provide effective penalties," 32 while the Torture Convention requires only that states "submit" cases involving allegations of torture to the "competent authorities for the purpose of prosecution" and merely requires the state to make torture "punishable by appropriate penalties which take into account their grave nature." ${ }^{33}$ Thus, the Torture Convention, these commentators assert, "does not explicitly require that a prosecution take place, let alone that punishment be imposed and served." ${ }^{34}$

Such an argument misconstrues the nature of the "prosecute or extradite" formulation used in the Torture Convention, which is reproduced verbatim in several other modern international criminal conventions. ${ }^{35}$ The Torture Convention was carefully worded to reflect the developments in international standards of due process that had occurred in the nearly forty years since the

27. Torture Convention, supra note 26 , art. 1.

28. See id. art. 4. The A rticle also requires parties to criminalize acts which "constitute[] complicity or participation in torture." Id.

29. Seeid. art. 5 .

30. See id. art. 7.

31. See O rentlicher, supra note 9, at 2604; J ose Zalaquett, Confronting H uman Rights Violations Committed by Former G overnments: Principles A pplicable and Political Constraints, in STA TE CRIMES: PUNISHMENT OR PARDON 42 (1989).

32. See $G$ enocide Convention, supra note 22 , arts. 4,5 .

33. See Torture Convention, supra note 26 , arts. 7(1), 4(2).

34. O rentlicher, supra note 9 , at 2604.

35. See, e.g., Convention for the Suppression of Unlawful Seizure of A ircraft, 22 U.S.T. 1641, T.I.A.S. N o. 7192, 860 U.N.T.S. 105 (signed Dec. 16, 1970; entered into force O ct. 14, 1971); Convention for the Suppression of U nlawful A cts A gainst the Safety of Civil A viation, 24 U S.T. 565, T.I.A.S. N o. 7570, 974 U.N.T.S. 177 (signed Sept. 23, 1971; entered into force J an. 26, 1973); Convention on the Prevention and Punishment of C rimes A gainst Internationally Protected Persons, including D iplomatic A gents, 28 U.S.T. 1975, T.I.A.S. N o. 8532, 1015 U .N.T.S. 243 (signed D ec. 14, 1973; entered into force Feb. 20, 1977); International Convention A gainst the Taking of H ostages, G.A. R es. 34/146, 34 U.N. G A OR, 34th Sess., Supp. N o. 46 at 245, U .N. D oc. A/34/146 (1979) (signed D ec. 17, 1979; entered into force J une 4, 1983), reprinted in 18 I.L.M. 1456 (1979); Convention for the Suppression of U nlawful A cts A gainst the Safety of M aritime Navigation, R ome, Mar. 10, 1988, and the Protocol for the Suppression of Unlawful A cts A gainst the Safety of Fixed Platforms L ocated on the Continental Shelf, R ome, M ar. 10, 1988, reprinted in 27 I.L.M . 668 (1988). 
Genocide Convention was drafted in 1948. Of particular importance was the adoption in 1966 of the International Covenant on Civil and Political Rights, which obligates states to ensure the rights of criminal defendants, including "the right to be presumed innocent," and the right "to take proceedings before a court, in order that that court may decide without delay on the lawfulness of his detention and order his release if the detention is not lawful." " 36 To be consistent with these rights, the Torture Convention had to be worded in such a way as to avoid the suggestion of a predetermined outcome of the judicial proceedings, and to recognize that there are legitimate reasons for the termination of an investigation or the dismissal of a case prior to trial. ${ }^{37}$

Nor should any significance be assigned to the slight difference in the wording of the two conventions' punishment clauses. The manifest intent of both conventions was to ensure that persons convicted of genocide or torture serve harsh sentences. In the view of the Torture Convention's drafters, "[i]n applying article 4 [, which requires states to make torture 'punishable by appropriate penalties which take into account their grave nature,'] it seems reasonable to require that the punishment for torture should be close to the penalties applied to the most serious offenses under the domestic legal system." ${ }^{38}$ Thus, this wording of the Torture Convention should not be construed to suggest the permissibility of amnesties or pardons.

U nfortunately, the majority of countries in the world (including most of those cited above) are not party to the Torture Convention. Still, some might argue that the Convention is nonetheless relevant based on the Committee A gainst Torture's 1990 decision concerning the A rgentinean amnesty laws. In that case, the Committee A gainst Torture, which is the treaty body created by the Torture Convention to facilitate its implementation, decided that communications submitted by A rgentinean citizens on behalf of their relatives who had been tortured by A rgentinean military authorities were inadmissible since A rgentina had ratified the Convention only after the amnesty laws had been enacted. However, in dictum, the Committee stated, "Even before the entry into force of the Convention against Torture, there existed a general rule of international law which should oblige all states to take effective measures to prevent torture and to punish acts of torture." ${ }^{39}$

The Committee's statement should not be mistakenly construed as suggesting that amnesties for persons who commit torture are invalid under customary international law. By using the word "should," the Committee indi-

36. International Covenant on Civil and Political Rights, opened for signature D ec. 19, 1966, 999 U.N.T.S. 171, arts. 9(4), 14(2). The International Covenant has been adopted by more than 100 states. See LoUISHENKIN ET AL., INTERNA TIONA L LA W: CA SESAND MATERIA LS 610 (3d ed. 1993).

37. See $O$ rentlicher, supra note 9 , at 2604 n.306.

38. J. HERMAn BuRgers \& HANS DANELIUS, The UNITEd NATIONS CONVENTION A gainst TORTURE: A HANDBOOK ON THE CONVENTION A GAINST TORTURE AND OTHER CRUEL, INHUMAN, OR DEGRADING TREATMENT OR PUNISHMENT 129 (1988).

39. D ecision on A dmissibility, dated November 23, 1989, Regarding Communications nos. 1/1988, 2/1988 and 3/1988 (O.R., M.M. and M.S. v. A rgentina), Report of the Committee A gainst Torture, U.N. G A O R, 45th Sess., Supp. N 0. 44, at annex VI, U .N . D oc. A /45/44, at 111 (1990). 
cated that its statement was aspirational rather than a declaration of binding law. On the basis of its decision, the Committee urged A rgentina to provide remedies for the victims of torture and their surviving relatives; it did not suggest that international law required that A rgentina do so. ${ }^{40} \mathrm{~N}$ or did it specify that the remedy should be prosecution of those responsible, rather than some other appropriate remedy such as compensation. The Committee's decision, therefore, can not be read as indicating that the Torture Convention requires non-parties to prosecute those who commit torture.

\section{B. General H uman R ights Conventions}

Unlike the international criminal conventions discussed above, "general human rights conventions" such as the International Covenant on Civil and Political Rights, ${ }^{41}$ the European Convention for the Protection of Human $\mathrm{R}$ ights and Fundamental Freedoms, ${ }^{42}$ and the A merican Convention on $\mathrm{H}$ uman $\mathrm{R}$ ights ${ }^{43}$ are silent about a duty to punish violations of the rights they were designed to protect. These general human rights conventions do, however, obligate states to "ensure" the rights enumerated therein.

Some commentators take the position that the duty to ensure rights implies a duty to prosecute violators. ${ }^{44}$ To support their position, the commentators point to the "authoritative interpretations" rendered by the Human Rights Committee, which was established to monitor compliance with the Covenant on Civil and Political Rights. ${ }^{45}$ The Committee is empowered to comment on communications received from individuals who are from states that have ratified the Optional Protocol to the Covenant and who claim to have suffered a violation of any of the rights protected by the Covenant. ${ }^{46}$ Three communications issued by the Committee have been cited as particularly noteworthy: In response to a communication alleging acts of torture in Zaire, the Committee issued a comment stating that Zaire was "under a duty to ... conduct an inquiry into the circumstances of [the victim's] torture, to punish those found guilty of torture and to take steps to ensure that similar violations do not occur in the fu-

40. Seeid.

41. A dopted D ec. 19, 1966, 999 U .N.T.S. 171 (entered into force M ar. 23, 1976).

42. Signed N ov. 4, 1950, 213 U .N.T.S. 222, E urop. T.S. N o. 5 (entered into force Sept. 3, 1953).

43. A dopted J an. 7, 1970, O.A.S. Official Records, OEA/ser.K/XVI/1.1, doc. 65 rev. 1, corr. 1 (1970), reprinted in 9 I.L.M. 673 (1970).

44. See R oht-A rriaza, supra note 2, at 467; O rentlicher, supra note 9, at 2568; Thomas Buergenthal, To Respect and To Ensure: State O bligations and Permissible Derogations, in THE INTERNA TIONAL BILL OF RIghtS: The COVEnANT ON CIVIL AND POLITICAL RIGHTS 77 (Louis Henkin ed., 1981) (noting that the "obligation to 'ensure' rights creates affirmative obligations on the state-for example, to discipline its officials"); Y oram D instein, The Right to L ife, Physical Integrity, and L iberty, in THE INTERNATIONAL BILL OF RIGHTS 119 (noting that parties to the Covenant arguably must exercise due diligence to prevent intentional deprivation of life by individuals, "as well as to apprehend murderers and to prosecute them in order to deter future takings of life").

45. See, e.g., O rentlicher, supra note 9, at 2568; Naomi Roht-A rriaza, Sources in International Treaties of an Obligation to Investigate, Prosecute, and Provide Redress, in IMPUNITY AND HUMAN RIGHTS IN INTERNA TIONA L LA W A ND PRA CTICE 28-30 (Naomi Roht-A rriaza ed., 1995).

46. See Optional Protocol to the International Covenant on Civil and Political Rights, G.A. Res. 2200A , 21 U .N. G A O R Supp. (N o. 16) at 59, art. 1, U .N. D oc. A /6316 (1966). 
ture." ${ }^{47}$ In response to a communication alleging extra-legal executions in Surinam, the Committee urged the government "to take effective steps ... to investigate the killings ... [and] to bring to justice any persons found to be responsible." 48 And in a case involving disappearances (forced abductions by state agents followed by denials of knowledge of the victims' whereabouts) in U ruguay, the Committee concluded that the government of U ruguay should take effective steps to bring to justice any persons found responsible. ${ }^{49}$

In addition, the $\mathrm{H}$ uman Rights Committee periodically adopts "General Comments" elaborating the nature of States Parties' obligations under particular articles of the Covenant. In 1992, the Committee issued a general comment asserting that amnesties covering acts of torture "are generally incompatible with the duty of States to investigate such acts; to guarantee freedom from such acts within their jurisdiction; and to ensure that they do not occur in the future." ${ }^{50}$

The authoritative interpretation rationale is based on the notion that Parties to the Covenant, having undertaken the treaty obligations contained therein, are subsequently bound to accept, for the purposes of interpreting these obligations, the interpretations rendered by the $\mathrm{H}$ uman R ights Committee. $^{51}$ This rationale, however, is a bit of an overstretch. During the negotiations of the Covenant, the delegates specifically considered and rejected a proposal that would have required states to prosecute violators. ${ }^{52}$ To read in such a requirement on the basis of the Human Rights Committee's comments would be to contravene the understanding of the Conventions' drafters upon which the majority of Parties relied when ratifying the Convention. N evertheless, an increasing number of commentators, as well as the states-parties themselves, seem to consider the Committee's comments as Covenant jurisprudence, and the countries that have more recently ratified the Covenant enter the system with full knowledge of this jurisprudence and an awareness that the Cold War context of the legislative history is increasingly obsolete. ${ }^{53}$

A Ithough the Human Rights Committee's pronouncements suggest a duty for the state to do something to give meaning to the rights enumerated in the Covenant, a careful reading of the Committee's comments reveals that the Committee never actually concluded that there was an obligation to prosecute attendant to the duty to ensure the rights provided in the Covenant. R ather,

47. M uteba v. Zaire, Comm. No. 124/1982, 39 U.N. G A OR Supp. (No. 40) A nnex XIII, U.N. Doc. A /39/40 (1984).

48. Boaboeram v. Surinam, Comm. Nos. 146/1983 and 148-154/1983, 40 U.N. G A OR Supp. (No. 40) A nnex X, ๆ 13.2, U .N. D oc. A /40/40 (1985).

49. See Quinteros v. U ruguay, Comm. No. 107/1981, 38 U .N. GA OR Supp. (No. 40) A nnex XXII, U .N. D oc. A/38/40 (1983). 1992).

50. General Comment No. 20 (44) (article 7), U.N. D oc. CCPR/C21/R ev.1/A dd.3, para. 15 (A pril

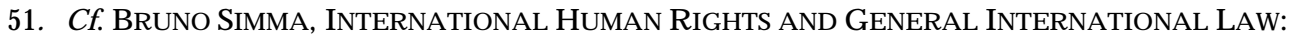
A COMPARATIVE ANALYSIS 223 (1995).

52. See U.N. ESCOR, Comm'n on Hum. Rts., 6th Sess., 195th Mtg. at 6, q 24, U.N. Doc. E/CN.4/SR .195 (1950).

53. See 0 rentlicher, supra note 9 , at 2568 ; N aomi R oht-A rriaza, supra note 45 , at $28-30$. 
the Committee "urged" Surinam to prosecute and said that U ruguay "should" bring violators to justice. Nor did the Committee state that Zaire had to undertake criminal prosecutions, but only that it had a duty to somehow punish those found guilty by an inquiry, thereby leaving the door open to alternative measures such as dismissal from the military or loss of military rank, canceling government pensions, banning the perpetrator from public office, and/or requiring the payment of damages through administrative fines or civil proceedings. The Committee's 1992 general comment is consistent with this interpretation. By stating that amnesties "are generally incompatible," the Committee implied that some amnesties-for example, those that are accompanied by investigations to document abuses and identify perpetrators, purging the perpetrators from positions of authority, and providing victim compensation-would be acceptable.

The authoritative interpretation rationale has more weight as applied to the decisions rendered by the Inter-A merican Court of H uman R ights interpreting the $\mathrm{A}$ merican Convention on $\mathrm{H}$ uman $\mathrm{R}$ ights. Commentators who argue that $\mathrm{a}$ duty to prosecute violators must be read into the A merican Convention have pointed to the Court's "landmark decision" in the Valasquez Rodriguez Case ${ }^{54}$ to support their position. ${ }^{55}$ That case concerned the unresolved disappearance of $\mathrm{M}$ anfredo $\mathrm{V}$ alasquez in September 1981. The Court heard testimony indicating that he had been tortured and killed by Honduran security forces. W riting of the duty under A rticle 1(1) of the A merican Convention to "ensure" rights set forth in the Convention, the court stated,

This obligation implies the duty of the States Parties to organize the governmental apparatus and, in general, all the structures through which public power is exercised, so that they are capable of juridically ensuring the free and full enjoyment of human rights. A s a consequence of this obligation, the States must prevent, investigate and punish any violation of the rights recognized by the Convention and, moreover, if possible attempt to restore the right violated and provide compensation as warranted for damages resulting from the violation. ${ }^{56}$

The Court then proceeded to find the H onduran government to be in breach of its duties under the Convention and ordered it to pay compensation to the victim's relatives. $^{57}$

O ne must be careful, however, not to read too much into the Valasquez Rodriguez Case with respect to the duty to prosecute violations of the A merican Convention. In particular, it is important to note that the Court, in ordering remedies, did not direct the Honduran government to institute criminal proceedings against those responsible for the disappearance of $\mathrm{M}$ anfredo V alasquez, notwithstanding the fact that the lawyers for the victims' families

54. See 4 Inter-A m. C.H.R. (ser. C) No. 4, ๆ 174 (1988) (judgment), reprinted in 3 TRANSITIONAL JUSTICE: HOW EMERGING DEMOCRACIES RECKON WITH FORMER REgIMES 586 (Neil Kritz ed., 1995).

55. See, e.g., D ianne O rentlicher, A ddressing G ross H uman Rights A buses: Punishment and Victim Compensation, in HUMAN RIGHTS: A N A GENDA FOR THE NEXT CENTURY 429 (L ouis Henkin \& John L. H argrove eds., 1995).

56. Valasquez, Inter-A m. Ct. H.R. (ser. C) N o. 4, ๆ 164.

57. Seeid. १ 194(5). 
and the Inter-A merican Commission had specifically requested such injunctive relief. ${ }^{58}$ Indeed, although the court said that "[s]tates must prevent, investigate and punish any violation of the rights recognized by the Convention," it did not specifically refer to criminal prosecution as opposed to other forms of disciplinary action or punishment.

In the wake of the 1989 V alasquez judgment of the Inter-A merican Court, the Inter-A merican Commission revisited the question of the permissibility of amnesty laws in cases concerning EI Salvador, U ruguay, and A rgentina. ${ }^{59}$ In all three cases, the Commission determined that the amnesties were incompatible with the A merican Convention's right to a remedy (A rticle 25 ) and right to judicial process (A rticle 8 ), read together with A rticle 1's obligation to ensure rights. $^{60}$ The rationale applies only to countries in which the amnesty affects the domestic law right to initiate or participate in public criminal process and which forecloses civil redress, which is intimately tied to criminal prosecution. ${ }^{61}$

The Inter-A merican Commission took its position a step farther in a 1996 decision concerning a complaint against Chile for failing to repeal the military regime's 1978 "self-amnesty" and its consequent failure to prosecute cases of disappearances, summary and extrajudicial executions, and torture. ${ }^{62}$ In that case, Chile's new democratic government had established an investigative commission, which issued a public report and awarded the following compensation to families of the victims: a pension not less than the average for Chilean families; expedited procedures to declare a presumption of the victim's death; special attention from the State with regard to health, education, and housing; assistance with debts; and exemption from obligatory military service for sons of victims. ${ }^{63}$ The Commission concluded:

The Government's recognition of responsibility, its partial investigation of the facts and its subsequent payment of compensation are not enough, in themselves, to fulfill its obligations under the Convention. ... [T] ]he State has the obligation to investigate all violations that have been committed within its jurisdiction, for the purpose of identifying the persons responsible, imposing appropriate punishment on them, and ensuring adequate reparations for the victims. ${ }^{64}$

However, the Commission's conclusion did not mean that a state must always bring prosecutions against the perpetrators of human rights crimes. $\mathrm{R}$ ather, according to the Commission, there were two main defects in Chile's approach: First, the state failed to conduct an investigation that specifically identified all individual perpetrators, which consequently "made it virtually impossible [for the victims] to establish any such responsibility before the civil

58. See R oht-A rriaza, supra note 45 , at 31.

59. See Inter-A m C.H.R., R ept. 26/92 OEA/ser. LN/II.82 (Sept. 24, 1992) (EI Salvador); InterA m C.H.R. R ept. 29/92 O E A/ser. L N /I I.82, D oc. 25 (O ct. 2, 1992) (U ruguay); Inter-A m C.H.R. R ept. 24/92 O E A /ser. L/V /I I.82, D oc. 24 (O ct. 2, 1992) (A rgentina).

60. Seeid.

61. See Naomi Roht-A rriaza, Special Problems of a Duty to Prosecute: Derogation, Amnesties, Statutes of L imitations, and Superior Orders, in I M PU NITY A ND H U MA N, supra note 45, at 62.

62. Gary H ermosilla et. al., case no. 10.843, I nter-A m C.H.R. (1988).

63. Id.at $171,957$.

64. Id. at $176,977$. 
courts." ${ }^{65}$ Second, the state failed to take any punitive action against the perpetrators. ${ }^{66}$ A t a minimum, this case suggests that under the general human rights conventions a state must conduct an investigation that specifically identifies perpetrators and must impose some form of punishment on those identified as responsible.

\section{Customary International L aw: Crimes A gainst H umanity}

Several scholars have recently taken the position that there is a customary international law duty to prosecute the perpetrators of crimes against humanity and that the granting of amnesty to those who commit such crimes is a violation of international law. ${ }^{67}$

The term "crimes against humanity" as the label for a category of international crimes recognized under customary international law originated in the joint declaration of the governments of France, Great Britain, and R ussia of $M$ ay 28, 1915, denouncing the Turkish massacre of more than a million A rmenians in Turkey as constituting "crimes against civilization and humanity" for which the members of the Turkish Government would be held responsible. ${ }^{68}$ The $C$ harter of the N uremberg $W$ ar C rimes Tribunal was the first international instrument in which crimes against humanity were codified. ${ }^{69}$ The basis for the inclusion of crimes against humanity in the Nuremberg Charter included the 1899 and $1907 \mathrm{H}$ ague Conventions, experiences, and practices in the aftermath of World War I and the A llied declarations during W orld W ar II. In addressing the defense claim of ex post facto law, the Nuremberg Tribunal concluded, "The Charter is not an arbitrary exercise of power on the part of the victorious nations, but in the view of the Tribunal, as will be shown, it is the expression of international law existing at the time of its creation; and to that extent is itself a contribution to international law."

The N uremberg Charter defined crimes against humanity as follows:

murder, extermination, enslavement, deportation, and other inhumane acts committed against any civilian population, before or during the war, or persecutions on political, racial, or religious grounds in execution of or in connection with any crime within the jurisdiction of the Tribunal [that is, crimes or crimes against peace], whether or not in violation of the domestic law of the country where perpetrated. ${ }^{11}$

65. Id. at 173,966 .

66. Seeid. at $172, \uparrow 63$.

67. See America's Watch, Special issue: A CCOUNTABILITy for Past Human Rights A BUSES 2 (DeC. 1989); M. CHERIF BASSIOUNI, CRIMES A GAINST HUMANITY IN INTERNATIONAL CRIMINAL LAW 492, 500-01 (1992); Edelenbos, supra note 12, at 15; Orentlicher, supra note 9, at 2585,2593

68. See B A SSIOUNI, supra note 67 , at 168 .

69. Seeid. at 1.

70. 22 Trial of the Major War Criminals Before the international Military TRIBUNA L 461 (1949), quoted in BA SSIOUNI, supra note 67, at 120.

71. Charter of the International M ilitary Tribunal annexed to the A greement for the Prosecution and Punishment of the Major War Criminals of the European A xis, A ug. 1945, 82 U.N.T.S. 279, 59 Stat. 1544, E.A.S. N o. 472 (entered into force A ugust 8, 1945), as amended by the Berlin Protocol of 6 O ctober 1995, reproduced in MORRIS \& SCHARF, supra note 13, at 73 n.234. 
U nder the Nuremberg Charter, the only difference between war crimes and crimes against humanity was that the former were acts committed against nationals of another state, while the latter were acts committed against nationals of the same state as that of the perpetrators. ${ }^{72}$ B oth had to be committed in connection with the war. ${ }^{73}$ While the N uremberg Tribunal ruled that it did not have jurisdiction over acts of persecution against G erman J ews committed before the beginning of the war in 1939, the judgment left unclear whether the Tribunal believed the linkage to war to be required by international law or merely by its charter. ${ }^{74}$

A Ithough at least one commentator has asserted that "the post-N uremberg developments have failed decisively to resolve the nexus issue," ${ }^{75}$ a quick survey of these developments should remove any doubt that the concept of crimes against humanity under customary international law now extends to atrocities committed during peacetime. First, the linkage to war was not included in the definition of crimes against humanity contained in Control Council Law N o. 10, which was adopted after the Nuremberg $C$ harter to provide a uniform basis for the trial of German war criminals other than the major war criminals tried by the N uremberg Tribunal. ${ }^{76}$ Second, in its authoritative report on the development of the laws of war at the conclusion of the N uremberg and Control Council Law No. 10 trials, the U nited Nations War Crimes Commission concluded that international law may now sanction individuals for crimes against humanity committed not only during war but also during peace. ${ }^{77}$ Third, in the International Law Commission's formulation of the Principles of International $L$ aw Recognized in the Charter of the N uremberg Tribunal and in the J udgment of the Tribunal, the International L aw Commission indicated that crimes against humanity of the inhuman act type could be committed apart from war, while it retained the restriction for crimes against humanity of the persecution type. ${ }^{78}$

72. See E gon Schwelb, Crimes A gainst H umanity, 23 B R ITISH Y .B. INT'L L. 206 (1946).

73. Seeid.

74. International M ilitary Tribunal, reprinted in 41 A M. J . INT'L L . 172, 248 (1947).

75. O rentlicher, supra note 9 , at 2590 .

76. See BASSIOUNI, supra note 67, at 35. The jurisprudence of the trials under Control Council Law No. 10, however, was mixed on whether crimes against humanity could be committed during peacetime. In the E isatzgruppen Case and the J ustice Case, the courts recognized that crimes against humanity were not limited to atrocities committed during a war. In the Flick Case and M inistries Case, the courts followed the precedent of the International $M$ ilitary Tribunal and required the connection to war notwithstanding the differences in the Nuremberg Charter and Control Council Law No. 10. See M ORRIS \& SCHARF, supra note 13 , at 75 n.242, 76 n.243.

77. A ccording to the $U$ nited Nations $W$ ar Crimes Commission, "[there exists] a system of international law under which individuals are responsible to the community of nations for violations of rules of international criminal law, and according to which attacks on the fundamental liberties and constitutional rights of people and individual persons, that is inhuman acts, constitute international crimes not only in time of war, but also, in certain circumstances, in time of peace." HISTORY OF THE UNITED NATIONS WAR CRIMES COMMISSION AND THE DEVELOPMENT OF THE LA WS OF WAR COMPILED BY THE UNITED NATIONS WAR CRIMES COMMISSION (1948), reprinted in BASSIOUNI, supra note 67, at 570.

78. The International $L$ aw Commission ("ILC") is a group of 34 distinguished international legal experts elected by the $U$ nited Nations $G$ eneral A ssembly with a mandate to encourage "the progressive development of international law and its codification." NEW ZEALAND MINISTRY OF EXTERNAL 
Fourth, the 1968 Convention on the N on-A pplicability of Statutory L imitations to $\mathrm{W}$ ar Crimes and Crimes A gainst $\mathrm{H}$ umanity provides in A rticle I that such limitations do not apply to "[c]rimes against humanity whether committed in time of war or in time of peace." ${ }^{79}$ Finally, the Secretary-G eneral's R eport on the Statute of the $Y$ ugoslavia Tribunal, which was prepared by the $U$ nited $\mathrm{Na}$ tions $O$ ffice of L egal Counsel on the basis of rules that were considered to be "beyond doubt customary international law," stated that international law now prohibits crimes against humanity "regardless of whether they are committed in an armed conflict." ${ }^{80}$ This statement was confirmed by the first decision of the A ppeals Chamber of the $Y$ ugoslavia Tribunal, which stated, "The obsolescence of the nexus requirement is evidenced by international conventions regarding genocide and apartheid, both of which prohibit particular types of crimes against humanity regardless of any connection to armed conflict." ${ }^{81}$

The Statute of the International Criminal Tribunal for $\mathrm{R}$ wanda, ${ }^{82}$ which constitutes the most recent codification of crimes against humanity, grants the Tribunal "the power to prosecute persons responsible for the following crimes when committed as part of a widespread or systematic attack against any civilian population on national, political, ethnic, racial or religious grounds: (a) murder; (b) extermination; (c) enslavement; (d) deportation; (e) imprisonment; (f) torture; (g) rape; (h) persecutions on political, racial, and religious grounds;

Relations and TRADE, 1992 UnITEd Nations HandBoOK 25 (1992). In 1947, the U nited Nations General A ssembly directed the ILC to "formulate the principles of international law recognized in the Charter of the Nuremberg Tribunal and in the Judgment of the Tribunal." U.N. G.A. R es. 177 (II), N ov. 21, 1947. In 1950, the IL C adopted and submitted to the General A ssembly the Nuremberg Principles, which included the following formulation on crimes against humanity: "M urder, extermination, enslavement, deportation and other inhuman acts done against any civilian population, or persecutions on political, racial or religious grounds, when such acts are done or such persecutions are carried on in execution of or in connection with any crime against peace or any war crime." BA SSIOUNI, supra note 67 , at 480.

79. Convention on the Non-A pplicability of Statutory Limitations to War Crimes and Crimes A gainst H umanity, 754 U .N.T.S. 73.

80. Report of the Secretary-General Pursuant to Paragraph 2 of Security Council Resolution 808 (1993), 3 M ay 1993, U .N. D oc. S/25704, reproduced in M ORRIS \& SCHAR F, supra note 13, at 81 n.260. The submission of the Commission of Experts established by Security Council R esolution 780, as well as the submissions of other organizations and states, expressed the view that the Y ugoslavia Statute should define crimes against humanity irrespective of armed conflict. No state or organization took the position that crimes against humanity under international law could be committed only during war. See M ORRIS \& SCHARF, supra note 13 , at 82 n.262. The actual statute, however, provides that the Tribunal has jurisdiction over crimes against humanity only "when committed in armed conflict." See id. at 13 (article. 5). This restriction was a result of the context in which the Y ugoslavia Tribunal was created, rather than a reflection of a rule of customary international law. See id. at 83-84.

81. Decision on the D efense M otion for Interlocutory A ppeal on J urisdiction, U .N. International Tribunal for the Prosecution of Persons R esponsible for Serious V iolations of International H umanitarian Law Committed in the Territory of Former Y ugoslavia since 1991, Case N o. IT-94-1 at 72, O ct. 2, 1995.

82. The R wanda Tribunal was created by the U.N. Security Council, acting under Chapter VII of the U.N. Charter, in response to continuing reports of "genocide and other systematic, widespread and flagrant violations of international humanitarian law committed in R wanda." U.N. S.C. R es. 955, SCOR (1994). 
and (i) other inhumane acts." ${ }^{83}$ This definition of crimes against humanity contains four general criteria, namely: the acts must be inhumane in character, ${ }^{84}$ widespread or systematic, ${ }^{85}$ directed against a civilian population, and committed on national, political, ethnic, racial, or religious grounds. ${ }^{86}$

The first criterion distinguishes crimes against humanity from lawful acts (for example, imprisonment or deportation) done pursuant to a valid judicial or administrative decision following a full and fair hearing. The second criterion requires that the inhumane acts be widespread or systematic rather than isolated inhumane acts or random acts of violence. The third criterion indicates that crimes against humanity are restricted to inhumane acts committed against civilians as distinguished from members of the armed forces. The fourth criterion, which includes acts committed on political grounds, highlights a critical difference between crimes against humanity under customary international law and the crime of genocide which the Genocide Convention defines to exclude acts directed against "political groups."

Traditionally, those who committed crimes against humanity, were treated, like pirates, as hostis humani generis (an enemy of all humankind), and any state, including their own, could punish them through its domestic courts. ${ }^{87}$ In the absence of a treaty containing the aut dedere aut judicare (extradite or prosecute) principle, this so called "universal jurisdiction" is generally thought to be permissive, not mandatory. A s noted above, however, several commentators have recently taken the position that customary international law not only establishes permissive jurisdiction over perpetrators of crimes against humanity, but also requires their prosecution and conversely prohibits the granting of

83. Id. at A rticle 2 (paragraphing omitted). This definition departs slightly from that contained in the Statute of the Yugoslavia Tribunal. It replaces the phrase "when committed in armed conflict, whether international or internal in character, and directed against any civilian population" found in the article on crimes against humanity in the Statute of the $Y$ ugoslavia Tribunal with the phrase "when committed as part of a widespread or systematic attack against any civilian population on national, political, ethnic, racial, or religious grounds."

84. This is indicated by the phrase "other inhumane acts." The canon of construction known as ejusdem generis suggests that the listed crimes preceding "other inhumane acts" must be construed to be limited to things of the same kind. The crimes listed include all of the inhumane acts enumerated in the Nuremberg definition, with the addition of three inhuman acts that were expressly recognized as being of such gravity as to qualify as crimes against humanity in Control Council Law No. 10, namely, imprisonment, torture, and rape. See BA SSIOUNI, supra note 67, at 35.

85. A Ithough the phrase "widespread or systematic" does not appear in the N uremberg Charter, it is synonymous with the phrase "committed against any civilian population" as used in the Nuremberg definition. See Schwelb, supra note 72, at 191 (concluding that the phrase any civilian population "indicates that a larger body of victims is visualized and that single or isolated acts committed against individuals are outside its scope").

86. The requirement that the attack must be on "political, ethnic, racial or religious grounds," is drawn from the N uremberg Charter's reference to "persecutions." This requirement was not included in the Statute of the $Y$ ugoslavia Tribunal, and an argument can be made that it unnecessarily blurs the distinction between the two different types of crimes against humanity recognized at Nuremberg, namely, inhumane act-type crimes and persecution-type crimes. On the other hand, the drafters may have meant for this requirement merely to clarify that crimes against humanity are restricted to acts committed as part of state action or policy. See BA SSIOU NI, supra note 67, at 248-50.

87. See R oht-A rriaza, supra note 45 , at 25 . 
amnesty to such persons. ${ }^{88}$

Customary international law, which is just as binding upon states as treaty law, ${ }^{89}$ arises from "a general and consistent practice of states followed by them from a sense of legal obligation" referred to as opinio juris. ${ }^{90} \mathrm{U}$ nder traditional notions of customary international law, "deeds were what counted, not just words." ${ }^{91}$ Y et, those who argue that customary international law precludes amnesty for crimes against humanity base their position on non-binding ${ }^{92} \mathrm{G}$ eneral A ssembly Resolutions, ${ }^{93}$ hortative declarations of international conferences, ${ }^{94}$

88. See E delenbos, supra note 12 , at 15; O rentlicher, supra note 9, at 2585, 2593; B A SSIOUNI, supra note 67, at 492, 500-01; A MERICA'S W A TCH, supra note 67.

89. While customary international law is binding on states internationally, not all states accord customary international law equal domestic effect. A growing number of states' constitutions not only incorporate customary international law automatically as part of the law of the land but also grant it a rank superior to that of domestic statutes. See SIM M A supra note 51, at 213. In the U nited States, customary international law is deemed incorporated into the common law of the $U$ nited States but is considered controlling only where there is no contrary treaty, statute, or executive act. See, e.g., G arciaM ir v. M eese, 788 F.2d 1446 (11th Cir. 1986) (holding that A ttorney-G eneral's decision to detain M ariel Cuban refugees indefinitely without a hearing trumped any contrary rules of customary international law). For a criticism of the analysis in Garcia-M ir, see Jordan J. Paust, Paquete and the President: R ediscovering the B rief for the U nited States, 34 V A . J . INT'L L. 981, 989 (1994).

90. Restatement (Third) of the Foreign R elations Law of the U nited States $\S 102(2)$ (1987); Statute of the International Court of J ustice art. 38(1)(b), 59 Stat. 1055, 1060 (1945) (noting that sources of international law applied by the Court include "international custom, as evidence of a general practice accepted as law").

91. SIMMA, supra note 51 , at 216 .

92. See 0 scar Schacter, International $L$ aw in Theory and Practice, 178 REC. DES CoURS 111-21 (1982-V) ("U nder the U nited Nations Charter, the General A ssembly does not have the legal power to make law or to adopt binding decisions except for certain organizational matters such as procedural rules, regulations for the Secretariat and subsidiary bodies and financial decisions." ).

93. See, e.g., D eclaration on Territorial A sylum, G.A. R es. 2312, 22 U .N. GA O R Supp. (No. 16) at 81, U.N. D oc. A/6716 (1967) (states shall not grant asylum to "any person with respect to whom there are serious reasons for considering that he has committed a ... crime against humanity"); U nited $\mathrm{Na}$ tions Resolution on War Criminals, G .A . R es. 2712, 25 U.N. G A O R Supp. (N o. 28) at 78-79, U.N. Doc. A /8028 (1970) (adopted by a vote of 55 in favor to 4 against with 33 abstentions) (condemning crimes against humanity and "[C]all[ing] upon the [s]tates concerned to bring to trial persons guilty of such crimes"), reprinted in BASSIOUNI, supra note 67, at 698; G.A. R es. 2840, 26 U.N. GA OR Supp. (No. 29), at 88, U.N. D oc. A/8429 (1971) (adopted by a vote of 71 in favor to none against with 42 abstentions) (affirming that a state's refusal "to cooperate in the arrest, extradition, trial and punishment" of persons accused or convicted of crimes against humanity is "contrary to the U nited Nations Charter and to generally recognized norms of international law"); P rinciples of International Cooperation in the D etection, A rrest, Extradition, and Punishment of Persons $G$ uilty of War Crimes and Crimes A gainst Humanity, G.A. Res. 3074, 28 G A OR Supp. (N o. 30) at 79, U.N. D oc. A /9030 (1973) (adopted by a vote of 94 in favor to none against with 29 abstentions) (indicating that crimes against humanity "shall be subject to investigation and the persons against whom there is evidence that they have committed such crimes shall be subject to tracing, arrest, trial and, if found guilty, to punishment"), reprinted in 13 I.L.M. 230 (1974); Principles on the E ffective Prevention and Investigation of Extra-L egal, A rbitrary and Summary Executions, G.A. R es. 1989/65 (1989) (indicating that states shall bring to justice those accused of having participated in extra-legal, arbitrary, or summary executions); D eclaration on the Protection of All Persons From Enforced D isappearances, G .A. R es. 47/133 (1992) (equating disappearances to a crime against humanity and requiring states to try any person suspected of having perpetrated an act of enforced disappearance). It is noteworthy that large numbers of countries abstained during voting on the above listed resolutions, and thereby did not manifest their acceptance of the principles enumerated therein.

94. See, e.g., The D eclaration and Programme of A ction of the $1993 \mathrm{~W}$ orld Conference on H uman R ights, which affirms that "[s]tates should abrogate legislation leading to impunity for those responsible for grave violations of human rights such as torture and prosecute such violations, thereby provid- 
and international conventions that are not widely ratified, ${ }^{95}$ rather than on any extensive state practice consistent with such a rule.

Commentators often cite the Declaration on Territorial A sylum ${ }^{96}$ as the earliest international recognition of a legal obligation to prosecute perpetrators of crimes against humanity. The Declaration provides that states shall not grant asylum "to any person with respect to whom there are serious reasons for considering that he has committed a ... crime against humanity." $Y$ et, according to the historic record of this resolution, "[t]he majority of members stressed that the draft declaration under consideration was not intended to propound legal norms or to change existing rules of international law, but to lay down broad humanitarian and moral principles upon which [s]tates might rely in seeking to unify their practices relating to asylum." ${ }^{17}$ This evidences that, from the onset, the General A ssembly envisioned its role as advisory rather than creating a binding duty to prosecute crimes against humanity.

To the extent any state practice in this area is widespread, it is the practice of granting amnesties or de facto impunity to those who commit crimes against humanity. Indeed, no sooner had the term "crimes against humanity" been first coined with respect to the massacres of A rmenians during World War I, than the international community agreed to an amnesty for the Turkish perpetrators. $^{98}$ Prosecution was also forsaken after the A Igerian war, when, pursuant to the Evian A greement of 1962, France and A Igeria decided against trying persons who had committed atrocities. ${ }^{99}$ Similarly, after the B angladesh war of 1971, India and B angladesh consented not to prosecute Pakistani charged with genocide and crimes against humanity in exchange for political recognition of Bangladesh by Pakistan. ${ }^{100}$ Finally, as mentioned above, a score of countries,

ing a firm basis for the rule of law." World Conference on H uman Rights, Declaration and Programme of A ction, J une 1993, U.N. D oc. A /C onf./57/23, second part.

95. See, e.g., the Convention on the N on-A pplicability of Statutory L imitations to $W$ ar Crimes and Crimes A gainst H umanity, done in N ov. 26, 1968, 754 U.N.T.S. 73 (entered into force Nov. 11, 1970) (no statutory limitation shall apply to crimes against humanity, irrespective of the date of their commission), reprinted in 8 I.L.M. 68 (1969). A s of D ecember 31, 1994, the Convention had been ratified by only 39 states. See Multilateral Treaties D eposited with the Secretary-G eneral: Status as of December 31, 1994 (1995).

96. G.A. Res. 2312, 22 U .N. G A O R Supp. (No. 16) at 81, U.N. D oc. A /6716 (1967).

97. 1967 U .N.Y.B. 759.

98. See Schwelb, supra note 72, at 182. I nitially, the A Ilied Powers sought the prosecution of those responsible for the massacres. The Treaty of Sevres, which was signed on A ugust 10, 1920, would have required the Turkish Government to hand over those responsible to the Allied Powers for trial. Treaty of Peace between the A llied Powers and Turkey [Treaty of Sevres], art. 230, at 235, A ug. 10, 1920, reprinted in 15 A M. J . INT'L L. 179 (Supp 1921). "The Treaty of Sevres was, however, not ratified and did not come into force. It was replaced by the Treaty of Lausanne, which not only did not contain provisions respecting the punishment of war crimes, but was accompanied by a 'D eclaration of A mnesty' of all offenses committed between 1914 and 1922." Treaty of Peace between the Allied Powers and Turkey [Treaty of L ausanne], J uly 24, 1923, L eague of $N$ ations Treaty Series 11, reprinted in 18 A M. J. INT'L L. 1 (Supp. 1924).

99. See E delenbos, supra note 12 , at 13 .

100. See BA SSIOUNI, supra note 67, at 228-30. D uring the war of Bangladesh's independence, W est Pakistan troops killed approximately one million E ast Pakistanis who supported efforts to establish the independent nation of $\mathrm{B}$ angladesh. India and $\mathrm{B}$ angladesh initially agreed to bring charges of genocide 
often with the blessing of the $U$ nited $\mathrm{N}$ ations, have granted amnesty to perpetrators of what ostensibly appear to fall within the definition of crimes against humanity.

Those who take the position that there is a customary international law duty to prosecute crimes against humanity respond to the litany of contrary state practice by asserting that "even those states which have adopted amnesty laws and thereby allowed impunity do not deny the existence, in principle, of an obligation to prosecute, but invoke countervailing considerations, such as national reconciliation or the instability of the democratic process." ${ }^{101}$ Support for this line of reasoning can be found in the I nternational C ourt of J ustice's J udgment in the Nicaragua case ${ }^{102}$ and in the oft-cited opinion of the U.S. Court of A ppeals for the Second Circuit in the Filartiga case. ${ }^{103}$

There are several problems with this argument in the context of the duty to prosecute crimes against humanity, however. First, it is factually incorrect. A Ithough a few of the states that have granted amnesty to the leaders of the former regime have characterized their action as an exception to the rule, ${ }^{104}$ most never mention the existence of a rule at all. A second problem stems from the fact that the nature of the obligation to prosecute such crimes is purportedly absolute. ${ }^{105}$ A s a consequence, appeals to exceptions or justifications suppos-

and crimes against humanity against 195 of the 10,000 Pakistani troops who had been captured by India. M eanwhile, Pakistan filed a case before the International Court of J ustice to compel India to repatriate the Pakistani troops. Ultimately, political considerations prevailed and in 1973 Bangladesh and India agreed not to prosecute the Pakistani prisoners in exchange for political recognition of Bangladesh by Pakistan and the withdrawal of Pakistan's case against India before the International Court of J ustice. Id.

101. E delenbos, supra note 12 , at 21 ; cf. R oht-A rriaza, supra note 2, at 496-97.

102. The International Court of J ustice attempted to come to terms with the problem of inconsistency between actual practice and opinio juris as follows:

In order to deduce the existence of customary rules, the Court deems it sufficient that the conduct of States should, in general, be consistent with such rules, and that instances of State conduct inconsistent with a given rule should generally have been treated as breaches of that rule, not as indications of the recognition of a new rule. If a State acts in a way prima facie incompatible with a recognized rule, but defends its conduct by appealing to exceptions or justifications contained within the rule itself, ... the significance of that attitude is to confirm rather than to weaken the rule.

Case Concerning M ilitary and Paramilitary A ctivities in and A gainst Nicaragua, 1986 I.C.J . 14, 1186.

103. In Filartiga v. Pena-I rala, 630 F. 2d 876 (2nd Cir. 1980), the Court observed:

The fact that the prohibition of torture is often honored in the breach does not diminish its binding effect as a norm of international law. A s one commentator has put it "The best evidence for the existence of international law is that every actual State recognizes that it does exist and that it is itself under an obligation to observe it. States often violate international law, just as individuals often violate municipal law; but no more than individuals do states defend their violations by claiming that they are above the law.

Case A gainst Nicaragua, 1986 I.C.J. at 9186 n.15 (quoting J. BRIERLY, THE OUTLOOK FOR INTERNATIONAL LA W 4-5 (1944)).

104. See R oht-A rriaza, supra note 2, at 496-97 (citing examples of Chile in 1984, U ruguay in 1986, A rgentina in 1987, and E I Salvador in 1987).

105. Several commentators have argued that the duty to prosecute crimes against humanity is jus cogens, or a peremptory norm of international law, which supersedes all other principles, norms, and rules of both international and national law. The essential characteristic of jus cogens as a higher rule 
edly contained within the rule do not in fact confirm the rule, but rather deny its existence and in its place assert an alternative rule that would allow amnesty for crimes against humanity whenever justified by needs for political reconciliation. A final problem is that the reasoning relied upon by the International Court of J ustice and the Second Circuit really makes sense only with respect to a situation where customary law has gradually been built up through State practice, and where instances of inconsistent conduct subsequently occur. ${ }^{106}$ The reasoning is much less convincing where, as in the case of a duty to prosecute crimes against humanity, the inconsistency between words and practice has been glaring from the very beginning. ${ }^{107}$

Thus, notwithstanding an array of $G$ eneral A ssembly resolutions calling for the prosecution of crimes against humanity and the strong policy and jurisprudential arguments warranting such a rule, the practice of states does not yet support the present existence of an obligation under customary international law to refrain from conferring amnesty for such crimes.

\section{Security Council R esolutions}

The Security Council can, through a Chapter VII resolution, create binding obligations on states to bring individuals responsible for international crimes to justice. The Council, for example, adopted R esolution 748, requiring Libya to surrender to the $U$ nited States or the $U$ nited $K$ ingdom for prosecution the two Libyan officials charged with bombing Pan A merican Flight $103 .{ }^{108}$ A year later, the Council adopted Resolution 837, calling for the arrest of Somali Warlord M ohamed Farrah A idid, who was responsible for the murder of 24 U .N. peacekeepers. ${ }^{109}$ In addition, the Security Council resolutions establishing the $Y$ ugoslavia and $R$ wanda $W$ ar Crimes Tribunals ${ }^{110}$ impose an obligation on all states that are members of the $U$ nited Nations to cooperate fully with the Tribunal, including its orders of arrest.

During the negotiation of the Dayton A ccord, the Chief Prosecutor of the Y ugoslavia Tribunal, Richard Goldstone, stressed that even if the peace agreement offered immunity to indicted war criminals, "[w]e would not be bound by it." He added that the Tribunal would continue with proceedings against such persons unless the Tribunal's Statute was changed by the U nited Nations Security Council. ${ }^{111}$ Moreover, notwithstanding any amnesty that

is its nonderogability. It admits of no exceptions such as force majeure or state of necessity. See Naomi Roht-A rriaza, Introduction, in IMPUNITY AND HUMAN RIGHTS, supra note 45, at 6; BASSIOUNI, supra note 67, at 489-99; O rentlicher, supra note 9, at 2609.

106. See SIM MA, supra note 51 , at 220.

107. Seeid.

108. S.C. Res. 748, SCOR (1992).

109. S.C. Res. 837, SCOR (1993). The Council rescinded this resolution when A idid retaliated by stepping up attacks on U.N. troops. See S.C. R es. 885 (1993).

110. See S.C. R es. 885, SCOR (M ay 25, 1993) (approving statute for the Y ugoslavia Tribunal); S.C. R es. 955 (N ov. 8, 1994) (approving statute for the R wanda Tribunal).

111. See Roger Cohen, U.N. in Bosnia: B lack Robes Clash with Blue Hats, N.Y. TIMES, A pr. 25, 
might have been included in the Dayton A ccord, the parties to the A ccord would still be bound by their obligations to arrest and surrender indicted war criminals to the Tribunal.

Whether such an obligation applies to the NATO Peace Implementation Force ("SFOR") is an open question. SFOR has reportedly come across indicted war criminals on several occasions, yet has failed to arrest them for transfer to the Tribunal. In A ugust 1996, when SFOR inspectors learned that General R atko M ladic was inside a bunker they had planned to inspect, they rescheduled their visit rather than confront the indicted war criminal. In M arch of 1996, A mnesty International sent an Open Letter to SFOR Commanders and Contributing $G$ overnments, which argued that SF O R 's failure to search for and arrest indicted war criminals was a violation of Security Council R esolution 827. Legal Counsel to SFOR responded that there is no such obligation on IFOR since the obligation is on the states, not NATO, and SFOR "is not an occupying force in B osnia." 112 This rationale, however, seems to fly in the face of A rticle 48 (2) of the Charter of the $U$ nited Nations, which requires members to carry out the decisions of the Security Council under Chapter VII of the Charter "directly and through their action in the appropriate international agencies of which they are members," which would include NATO.

III

\section{CONCLUSION}

D avid J. Scheffer, the U.S. A mbassador-at-L arge for War Crimes Issues, recently remarked that "one must understand, amnesty is always an option on the table in these negotiations." ${ }^{113}$ The above discussion indicates that A mbassador Scheffer is largely correct in that there are frequently no legal constraints to the negotiation of an amnesty for peace deal. This is because the procedural law imposing a duty to prosecute is far more limited than the substantive law establishing the underlying international offenses.

$Y$ et there are occasions where negotiators cannot legally consider an amnesty. Where atrocities occur during an international armed conflict, the Geneva Conventions require prosecution; where mass violence is directed at ethnic, national, racial, or religious groups, the Genocide Convention requires prosecution; and where persons under color of law commit acts of torture in a country that is a party to the Torture Convention, the Convention requires prosecution. A ny amnesty conferred in those limited circumstances would constitute a violation of treaty law and would be subject to challenge in a variety of domestic and international fora.

While the international criminal conventions are limited in their applica-

1995, at $\mathrm{A} 3$.

112. Col. Frederick Michael Lorenz, Peace Operations and War Criminals: Testing the Limits of Military Force (N ov. 17, 1996) (unpublished paper on file with author).

113. R emarks by D avid Scheffer at International L aw Weekend (Nov. 2, 1996). 
tion, there is growing recognition of a duty for states to do something to give meaning to the human rights enumerated in the Covenant on Civil and Political $\mathrm{R}$ ights, the $\mathrm{E}$ uropean Convention for the Protection of $\mathrm{H}$ uman $\mathrm{R}$ ights, and the A merican Convention on H uman R ights, which are much more likely to be applicable in a broad variety of situations. $Y$ et, the "something" required is not necessarily prosecution of former leaders responsible for violations of these general human rights treaties. Given the precedent discussed earlier, it is likely that the Committee on H uman R ights, the E uropean Court of H uman Rights, and the Inter-A merican Court of H uman R ights would all agree that measures short of prosecution-such as establishment of an investigative commission which specifically identifies perpetrators and victims, non-criminal sanctions against responsible officials and military personnel, and judicial redress for victims - would be adequate to discharge the duty to ensure human rights.

Customary international law recognizes permissive jurisdiction to prosecute persons responsible for crimes against humanity either nationally or before an international tribunal. Y et, despite, a large collection of $G$ eneral A ssembly R esolutions calling for prosecution of crimes against humanity, and notwithstanding the forceful arguments of several international legal scholars, state practice does not yet support the existence of an obligation under international law to refrain from conferring amnesty for crimes against humanity. That the $U$ nited Nations, itself, has felt free of legal constraints in endorsing recent amnesty for peace deals underscores this conclusion.

Once it is recognized that there is a gap in the international law requiring prosecution, two approaches are possible: one is to exploit the gap, the other is to attempt to fill it. This dichotomy is manifest in the gulf between the human rights machinery of the $U$ nited $N$ ations and the peacemaking functions centered in the Secretary-G eneral's O ffice and the Security Council. ${ }^{114}$ G iven the strong policy reasons to disfavor amnesties which are articulated by the other articles in this symposium issue, instead of brokering or endorsing amnesty-for-peace deals, the Security Council should play a preemptive role in situations in which it has become involved by providing in a Chapter VII resolution that no amnesty for the perpetrators of crimes against humanity shall be permitted or internationally respected. Likewise, the statute of the proposed permanent international criminal court should make clear that national amnesties will not be considered as a legitimate factor in the exercise of its prosecutorial discretion. ${ }^{115}$

114. See Naomi R oht-A rriaza, in I M PUNITY AND HUMAN RIGHTS, supra note 45, at 300.

115. A s the Prosecutor of the $Y$ ugoslavia W ar Crimes Tribunal, R ichard G oldstone, stressed: International justice requires that the decision to prosecute be made "without regard to political considerations or consequences." See MICHAEL P. SCHARF, BALKAN JUSTICE: THE STORY BEHIND THE First INTERNATIONAL WAR CRIMESTRIAL SINCE NUREMBERg 89 (1997). 